DOI 10.5937/kultura1547033C

УДК 316.42:172

172.16:316.324.8

141.7"20"

оригиналан научни рад

\title{
ПIEPMAHEHTHA КРИЗА
}

Сажетак: Појам кризе везује се пре свега за економску кризу па тако у први план пробија питање о односу капитализма и криза. Да ли је криза нешто што споља нарушава нормално функиионисање система и претпоставља кратко трајање, чему следи успостављање равнотеже и враћање у нормалан процес тржииног регулисањ а и подешавања? Или је криза суштинска и непромењива одлика капиталистичког начина производње из чега следи да се капитализам историјски испоставља као непрекидно кретање из једне кризе у другу што указује на перманентну кризу као главно обележје позног капитализма и садашњег тренутка? Које су консеквенце уласка у перманентну кризу?

Кључне речи: криза, капитализам, хуманизам, постхуманизам, биополитика, биомаса

Ако се о данашњој кризи размишља као о „тачки преокрета" од које започиње промена, онда само лоцирање ове тачке претпоставља неко одређење природе тог догађаја као и могуће линије које се даље из њега развијају. Ове линије оцртавају виртуелне честице догађаја које се, у зависности од околности, могу актуелизовати у неком будућем стању ствари и тако реконфигурисати стабилизоване контексте и њихов смисао унутар доминантне реалности система. Заправо, пре би се могло говорити о промени глобалног контекста чији се ефекти, унутар различитих локалних контекста, преламају на безброј начина.

У овом тренутку могуће је указати барем на три линије чије су почетне тачке различито позициониране на стрели времена, али које се надопуњују формирајући оно што би се могло назвати перманентном кризом. Прву од ових линија оцртава Слотердајк показујући да је са појавом масовних медија и масовне културе коегзистенција људи постављена на нове основе. Тако је истовремено хуманистички модел припитомљавања варварских импулса изгубио своју 
вековну ексклузивност, чиме су се створили услови да се контрола бестијалних и варварских сила измести у раван генетског инжињеринга. Другу, у својим анализама биополитике, готово успут, помиње Фуко одређујући је као вишак био-моћи. Та линија оцртава потенцијале чија би актуелизација премашила сваку људску сувереност, што имплицира могућност стварања не-људских ентитета који измичу људској контроли. Најзад, трећа линија започиње са оним што се назива хипотезом о „великом убрзању” и тиче се, пре свега, човековог утицаја на земљин систем, мада се у уметности, посебно на филму, ефекти овог убрзања већ оцртавају унутар онога што је Делез назвао кризом делатне слике.

Многа разматрања ове тачке преокрета, или кризе хуманистичког модела, гравитирају око појаве техничке репродукције, као оног топоса од којег започиње радикална промена односа сила. Ова промена започиње управо у тренутку када је хуманистички модел, који свој замах добија Гутенберговом техничком револуцијом, достигао свој врхунац и остварио готово апсолутну хегемонију. У есеју о техничкој репродукцији из 1936. године Бењамин ће ефекте појаве нове технике репродуковања упоредити са експлозијом која је стари, окамењени свет дигла у ваздух и створила услове, како за кретање или лутање између тих разбацаних фрагмената, тако и за другачије не-линеарно повезивање најразличитијих фрагмената. Сам ће Бењамин напоменути да ефекти ове промене далеко превазилазе испразну расправу о томе да ли су фотографија и филм уметност. Оно што је измицало свим учесницима у овој дискусији је управо то да ова промена доводи у питање, не само доминацију хуманистичког модела, већ и само функционисање тог модела у новој историјској констелацији. Тако се tehne сада појављује као опасност која, не само што разара хуманистички модел, већ, по мишљењу многих аутора, не нуди никакав други модел који би надоместио претходни. Утолико би се могло рећи да су Хајдегерови списи о техници као и његово разматрање хуманизма и уметности компатибилни у свом настојању да на нове основе поставе питање односа tehne и humanitas.

Слотердајков одговор на Хајдегерово „Писмо о хуманизму”, могао је у време свог настанка ${ }^{1}$ изазвати бурне реакције, због радикалног преиспитивања важећег модела хуманизма, а потом и због неочекиваног отварања епохалног питања о постхуманом. Данас се овај текст пре може читати као покушај да се лоцира тачка преокрета на стрели времена од које започиње промена: дакле, онај тренутак када постојећи

1 Die Zeit, (16. 9. 1999) Nr. 38. 
хуманистички модел коегзистенције људи у модерним масовним друштвима, није више толико делатан, а у скоријој будућности, велика је вероватноћа, да више неће ни важити.

Како Слотердајк оцртава основну матрицу овог модела? По његовом суду прећутна претпоставка од које полази структурирање хуманистичког модела је да људе високе културе обликују две силе: једна која отвара простор оном варварском, животињском и бестијалном и друга која тај простор затвара, ограничава, односно, припитомљује ове варварске импулсе. Тако се латентна тема читавог хуманизма може свести на питање како човека обузима дивљаштво, док се његова латентна теза, на којој се и заснива матрица хуманистичког модела, своди на поставку да „права лектира припитомљује". Овде се ничеански моменат припитомљавања испоставља као учинак дресуре и селекције: учинак онога што Ниче назива „културом” као доминацију реактивних сила. Читава се досадашња култура може разумети као „титанска борба” између импулса припитомљавања и бестијализовања пре свега преко њихових медија чији су основни модели литерарни клуб и римска гладијаторска арена.

Ако су књиге биле дебела писма пријатељима, онда је читав хуманизам могуће одредити као телекомуникацију у медију писма, ону која ствара пријатељства. Топологија те мреже писама, у времену и простору, оцртава обрисе хуманистичког модела, као доминантног унутар читаве досадашње културе писма. Заједнички фантазам свег хуманизма своди се тако на модел литерарног друштва у чијем срцу је фантазија секте или клуба, заправо, солидарност оних који су одабрани да буду писмени. Тако се селекција врши преко умрежавања оних одабраних, а дресура одређивањем корпуса канонске лектире и заједничкој љубави према инспиративном пошиљаоцу.

Али, као што је то случај са многим сектама, и хуманистички је пројекат задобио експанзионистичке и универзалистичке претензије. Тако се модел литерарног друштва, у 19. и 20. веку, као прагматичан и програмски, проширио на норме политичког друштва. Разлоге за то што је епоха хуманизма неповратно прошла треба тражити пре свега у томе што вештина писања писама више није била довољна за успостављање телекомуникацијских веза међу становницима модерног масовног друштва. Са појавом техничке репродукције, када маса постаје матрица, настаје масовна култура и културна индустрија чиме се коегзистенција људи у данашњим друштвима поставља на нове основе. Управо то успостављање нових основа за Слотердајка је тачка окрета, почетак незаустављиве промене, чија је основна одлика 
да је радикално постлитерална, постепистолографска, па самим тим и постхуманистичка.

Ако оно што се назива пост-хуманим треба разумети као слабљење хегемоније ове секте, или клуба хуманиста, као основне матрице досадашње културе писма, самим тим и префикс пост у новој констелацији превасходно указује на незаустављиве процесе маргинализације. У модерним друштвима, од појаве масовних медија, продукција политичке и културне синтезе, путем медија литературе, писма и хуманизма, у потпуности је маргинализована. Срушила се она илузија да се велике политичке и економске структуре могу организовати према моделу литерарног друштва што имплицира да ће наредни период човечанства, желели то или не, бити доба одлука о политици људског рода.

Са отварањем прве линије прећутно се претпоставља да је само питање времена када ће функцију хуманистичког припитомљавања преузети генетски инжењеринг што ће на дуги рок довести до „генетске реформе особина људског рода". Чини се да ће антропотехнологија будућности доспети до експлицитног планирања људских својстава, и барем из два разлога: први је унутрашњи и тиче се хуманистичког припитомљавања другим средствима; други је спољашњи и заснива се на самом опстанку људске врсте у потенцијално радикално промењеном систему земље.

Са овом променом само tehne, или тачније модерна техника, успоставља се као нова и непозната матрица, те је утолико Хајдегеров спис, не само о хуманизму већ и онај о техници постао незаобилазним штивом за разумевање промене. Но, управо се непознавање потенцијалних ефеката ове нове техно-матрице може исто тако сматрати и разлогом растуће опасности, јер не само што разара основну матрицу око које се структурирала досадашња култура, већ претпоставља битно другачији однос између припитомљавања и бестијализовања. Читав се постхуманизам, сасвим поједностављено, може разумети као замућивање граница, пре свега оне између човека, као анимал rationale и tehne. Припитомљавање више није само ствар културе у оном ничеанском смислу дресуре и селекције, већ ће у скорашњој будућности исто тако постати и ствар tehne, неке био-tehne као генетског инжињеринга или неког будућег когнитивног инжињеринга и сл. То не значи да ће tehne у потпуности искључити humanitas као модел припитомљавања дресуре и селекције. Напротив, већа је вероватноћа да ће се они преплитати и надопуњавати. 
Утолико постају јаснији разлози због којих се Хајдегер у свом „Писму о хуманизму”, супротставља управо дефинисању човека као animal rationale јер се човек разумева као animalitas проширен духовним и рационалним додацима. Хајдегеров се антивиталистички став заснива на поставци да се човек од животиње разликује по онтолошкој разлици, па се тако он не сме посматрати као животиња са културним или метафизичким додатком. Човек је пре свега биће језика (,Језик је кућа Битка, у њему пребивајући човек егзистира тако што припада истини Бића чувајући је.”). Језик у оваквом приступу не функционише као медиј споразумевања па самим тим и припитомљавања, као што је то случај са хуманизмом.

Дакле, са рушењем ове хуманистичке илузије намеће се потреба артикулисања епохалног питања: „ако је хуманизам као школа припитомљавања човека пропао, шта онда још припитомљује човека? Шта припитомљује човека уколико су његови досадашњи напори да сам себе припитоми, у ствари, довели само до тога да он освоји моћ над свим бивствујућим? Шта припитомљује човека ако је после свих досадашњих експеримената са васпитањем људског рода остало нејасно кога или шта васпитач васпитава, и због чега? Или се питање одгајивања и формирања човека на компетентан начин више и не може поставити само у оквиру теорије припитомљавања и васпитања?”2

\section{Друга линија}

Овако формулисана питања, посебно онај сегмент који се тиче освајања моћи „над свим бивствујућим”, у великој мери кореспондира са Фукоовим анализама преласка из дисциплине у биополитику, где се фокус моћи са појединачних „послушних тела” премешта на популацију. Али, овај прелазак не значи да настанак био-моћи искључује дисциплинарну моћ. Напротив, то претпоставља непрекидно надопуњавање два низа: низ, тело - организам - дисциплина - установе, уклапа се са низом, популација - биолошки процеси - регулациони механизми - држава. Са биополитиком власт је у 19. веку присвојила живот или преузела бригу над животом. Захваљујући двострукој игри технологије, дисциплине и техника регулације, она је успела да прекрије читаву површину: од органског до биолошког, од тела до популације. Власт је тако преузела бригу над животом уопште, где је на једној страни тело, а на другој популација. Управо

2 Слотердајк, П. (2001) У истом чамиу, Београд: Београдски круг, стр. 115. 
због тога што се технологија дисциплине и технологија регулације надопуњавају или укрштају у различитим диспозитивима, оне су конститутивни моменти хуманистичког припитомљавања варварских импулса. На тај начин овај нови склоп дисциплине и регулације који је у основи читаве биополитике, остаје унутар граница хуманистичког модела.

На крајњим тачкама вршења био-власти, међутим, појављују се и њени парадокси. На једној страни као први екстрем, налази се „атомска власт”, а на другој оно што Фуко назива „вишком био-власти”. Са могућношћу употребе атомског оружја, у случају „атомске власти” имамо употребу власти суверенитета која убија и чак може да убије и сам живот. У том случају се појављује вишак сувереног права тако да власт не може да буде био-власт, каква је од почетка 19. века, дакле, она која гарантује живот. Насупрот томе, други екстрем се појављује као „вишак био-власти” у односу на суверено право. „Вишак био власти се појављује када је човеку технички и политички дата могућност не само да уређује живот, већ да изазове умножавање живота, да производи живот, да производи чудовишта, да - у крајњем случају производи вирусе које је немогуће контролисати и који ће бити универзална пропаст. То је страховито ширење биовласти која ће, (насупрот атомској власти), превазићи сваки људски суверенитет."”

Са отварањем ове друге линије то страховито ширење биовласти, не само што пробија границе хуманистичког модела, већ прети да измакне свакој људској контроли. Оно што би у овом случају била тачка окрета је стварање политичких и технолошких услова за успостављање тог „вишка биовласти” као доминантног начина капиталистичке продукциje. У политичком смислу то је оно што се назива „новим духом капитализма”, „нео-либералним капитализмом” или већ..., али би се могло оцртати као: доминантни утицај финансијског капитала (колонизација будућности), приватизација јавних добара (вода, енергија, јавни сервиси), извлачење вишка вредности из готово свих социјалних активности, свођење свих аспеката живота на функцију тржишта, редефинисање људског бића као „власника” свог „људског капитала", тако да он постаје предузимач себе самог.

У технолошком смислу то је оно што се назива технологијом 21. века на чије је потенцијалне опасности, али и радикалну разлику у односу на технологију 20. века, међу првима указао Били Џој (Bily Јoy), полазећи од питања: да

3 Фуко, М. (1998) Треба бранити друштво, Нови Сад: Светови (Предавање на Колеж де Франсу из 1976. године), стр. 308. 
ли ће будућност уопште требати нас. У том контексту филм Transcendence (Wally Pfister, 2014) занимљив је барем из два разлога: први је реакција дела научне заједнице, а други настојање да се учини видљивим актуелизација виртуелних потенцијала нових технологија 21. века које конвергирају у ентитету који се назива Transcendence (вештачка интелигенција). Овај филм не спада у оне који ће се памтити по својим „уметничким” квалитетима - критика га је на самом старту отписала. Можда у томе пробија предрасуда критичара, с обзиром на то да је филм режирао директор фотографије у познатим холивудским блокбастерима (The Dark Knight Rises, Inception, The Dark Knight, Batman Begins, Insomnia итд.) па отуда примедбе о неизграђеним ликовима, разбијеном наративу и сл. Оно што ће вероватно остати запамћено је реакција Стивена Хокинга на филм у виду опомене да треба добро размислити пре него што се упустимо у даљи развој вештачке интелигенције (AI). ${ }^{4}$ Ова се опаска надовезује на, данас већ помало заборављени, текст Били Џоја у часопису Wired из 2004. године, у којем је указао на могуће последице неконтролисаног развоја технологије 21 . века. ${ }^{5}$ Он, пре свега, скреће пажњу на озбиљне и несагледиве импликације стварања самопрограмирајућих и самореплицирајућих машина, али и на то да се нова технологија развија изван било какве државне контроле унутар корпорација или чак малих старт-апова. На известан начин, реакције оба научника потврђују ону Фукоову опаску да са „вишком био-моћи” технологија 21. века може измаћи свакој људској контроли.

Но, могло би се поћи од тога да управо тај недостатак „уметничког” у филму доприноси ефекту (будуће) реалности који не желимо да видимо. Филм чини видљивим рецентна научна предвиђања скорашње будућности па самим тим и истину о једном неумитном кретању технологије о чијим ефектима смо можда прекасно почели да размишљамо. У овом случају би могли преокренути ону Ничеову опаску, па би се утолико могло рећи, да уметност више није у могућности да нас заштити од истине, што је у садашњем тренутку један од конститутивних момената њене маргинализације. Филм као

4 Stephen Hawking: 'Transcendence looks at the implications of artificial intelligence - but are we taking AI seriously enough?' ... One can imagine such technology outsmarting financial markets, out-inventing human researchers, out-manipulating human leaders, and developing weapons we cannot even understand. Whereas the short-term impact of AI depends on who controls it, the long-term impact depends on whether it can be controlled at all. www. independent.co.uk (приступљено 9. 5. 2014.)

5 Џој, Б. Заито нисмо потребни будућности, Врата панике. Тело, друштво и уметност у мрежи технолошке дереализачије, приредио Копицл, В. (2005), Нови Сад: Транс, стр. 209. 
да то потврђује јер би се читава прича могла свести на једно готово тривијално питање: шта заправо човечанство жели? Самим тим и које су то одлуке које се морају донети како би се та жеља остварила. Филм почиње промоцијом пројекта на којој брачни пар истраживача настоји да привуче нове донаторе тако што сасвим поједностављено објашњава шта је то сингуларност или трансценденција како је „генијални” научник назива. Према њиховом објашњењу вештачка интелигенција (AI) постиже ефекте готово магијских чуда те утолико делује логично питање из публике да ли они заправо желе да досегну бога. Пред крај филма, међутим, гледалац почиње да схвата да је то питање ирелевантно јер човечанство улази у доба када се пред њим постављају много сложенија, управо она Слотердајкова питања о будућности људског рода. Ова будућност осцилира између два екстрема. На једној страни ако, у духу садашњих тенденција капиталистичке продукције, технологија 21. века остане искључиво унутар бесмислене циркулације капитала, онда се, следећи његову логику профита, стварају услови да она измакне свакој људској контроли. То претпоставља пост-хуману будућност у којој је човек маргинализован у односу на машине. На другој страни, уколико се даљи развој нових технологија заустави, сценарио будућности ближи је оном из серијала Mad Max у којем је голи опстанак унутар рушевина досадашње цивилизације једина сврха постојања. Овај сценарио се чини веома могућим из простог разлога што је већ данас јасно да стара технологија 20. века више није у могућности да унутар постојећих ресурса задовољи основне потребе популације до средине 21. века.

Но, чини се да ово питање шта човечанство жели маскира друго, важније питање: није ли технологија 21. века почела да оцртава унутрашње границе капитализма каквог данас познајемо? Са „новим духом капитализма” човечанство се приближава спознаји да није сасвим сигурно да зна шта жели, тачније да се са унутрашњим границама капитализма оцртавају и унутрашње границе наших жеља, па самим тим и могућности одлучивања о властитој будућности. Сасвим поједностављено: проблем није у пребрзом развоју технологије већ у немогућности мишљења (имагинације) промене капиталистичког система који је у својој садашњој фази чак и жеље оне мањине, онај ултра привилеговани $1 \%$, свео на пуки клише, а оних других 99\% на голи живот или пуки опстанак. Но, управо та немогућност да замислимо крај капитализма, како је то приметио Фредерик Џејмсон, неосетно успоставља једну културу страха у којој је страх од нове технологије не само колатерални ефекат, већ и 
конститутивни моменат те немогућности мишљења будуће политике људског рода.

Унутар ове линије долази до померања на које у својим анализама биополитике указује Агамбен када показује како се ca bios (политички схваћеног живота) тежиште премешта на zoе (голи живот). Ако политика дисциплине претпоставља bios, онда биополитика са вишком био-моћи, претпоставља zое као стално отворену могућност да се унутар једног дела популације може применити нека од био-техника у сврхе „хуманистичког” припитомљавања. Zое као голи живот, оно што није ни на који начин заштићено, и логор као модел ретериторијализације било ког дела популације, тако постају два конститутивна момента за могућу примену неке био-tec$h n e$ као следећег корака био-политике која надопуњава ону прву линију хуманистичког припитомљавања. Тако се свака ретериторијализација у нео-либералној машини може трансформисати у логор, а унутар ње сваки bios у zoe, голи живот отворен за најразличитије генетске интервенције система. Те нове ретериторијализације нису фиксне ни просторно ни временски већ покретљиве и привремене.

\section{Перманентна криза}

Уобичајено значење кризе је пресуда, процена, резултат суђења, тачка преокрета, селекција, одлука, али исто тако и расправа, свађа, спор. Може бити и стандард из кога извлачимо мерило (критеријум), начин суђења, нешто круцијално, одлучујуће, пресудно, али и нешто што се тиче уметности просуђивања. У медицинском смислу то је прекретница, тачка преокрета у току болести, када наступа важна промена која указује било на опоравак или на смрт. На стрели времена то је тренутак или време интензивних тешкоћа, неприлика или опасности, време када се тешке или важне одлуке морају донети, кризне тачке историје. Унутар актуелног статуса стања ствари претпоставља се да је нека ситуација доспела у кризу, дошла до критичке тачке или прекретнице, раскршћа, момента истине, нултог часа, тачке без повратка, Рубикона, судњег дана и сл.

Данас се појам кризе везује пре свега за економску кризу па тако у први план пробија питање о односу капитализма и криза. Класични оријентисани економисти не прихватају да је криза инхерентна социјалној форми капиталистичке продукције. Њихове економске теорије полазе од премисе да је капитализам саморегулаторни систем, те је утолико потребно идентификовати минималне услове који ће омогућити одржавање ове саморегулације. Тако се сваки квар или дефект унутар система идентификује као изнимна девијација 
у односу на норму, па су утолико кризе контигентни феномени. Нормално функционисање система обезбеђује равнотежу, што имплицира да се кризе појављују као резултат или неког спољашњег удара (рат или природна катастрофа) или унутрашњих поремећаја (интервенција државе) чиме се повремено наруши равнотежа система. Узрок кризе је нешто спољашње у односу на саморегулацију система и претпоставља се да ће равнотежа убрзо бити успостављена захваљујући нормалном процесу тржишног регулисања и подешавања. На другој страни, за марксистички оријентисане теоретичаре кризе нису нешто спољашње и контигентно у односу на систем већ су инхерентне социјалној форми капиталистичке продукције. Уколико су кризе суштинска и непромењива одлика капиталистичког начина производње, онда оне оцртавају објективне границе капитализма, али и неопходност промене система. Као израз инхерентно контрадикторне форме капиталистичке продукције, кризе чине видљивом ону линију између „реформе” и „револуције”, између социјалне демократије која унутар капиталистичког система тражи институционалне реформе и револуционарних трагања за фундаментално различитим друштвеним системом.

Чини се да је две врсте догађаја могуће подвести под концепт кризе: први су побољшања (update-events) који су унутар система и побољшавају важећа правила игре. Други тип догађаја је „спољашњи” утолико што мења правила игре (game-changer event) и њихово потенцијално развијање може да има несагледиве, непредвидиве и непрорачунљиве последице за сам систем. У одређеним историјским околностима ови догађаји могу да доведу до „револуција” у различитим регистрима и могу, мада не нужно, да се прошире на читав систем.

Ако се капитализам историјски испоставља као непрекидно кретање из једне кризе у другу, онда је сваку кризу могуће разумети као један од ова два типа догађаја који на неки начин мења статус актуелног стања ствари. У првом случају, кризе у капитализму су побољшања (update) система, закрпе (patch) који крпе рупе унутар система, не доводећи у питање сам систем односно правила игре која су му инхерентна. Такве се кризе могу појављивати у различитим деловима система а да не угрожавају његове друге делове. Систем, заправо, никада не ради перфектно, напротив, он се непрекидно квари и багује, тако да су кризе као побољшања или закрпе, догађаји различитог интензитета и трајања који пробијају на критичним местима унутар топологије читавог поља. У другом случају, као догађаји који мењају правила 


\section{JОВАН ЧЕКИЋ}

игре (game-changer event), кризе не функционишу попут закрпе или побољшања система, мада не морају нужно да доводе сам систем у питање, оне пре свега мењају његов правац, брзину кретања, ритам и сл. па самим тим и топологију читавог поља. Тако се кризе, од средине 20. века, у периоду који се назива „великим убрзањем”, пре могу разумети као догађаји који мењају правила игре, него догађаји који крпе или побољшавају систем. Овај тип догађаја је веома тешко детектовати јер њихови симптоми и знакови нелинеарно и контингентно пробијају у различитим регистрима унутар система. Они се развијају различитим брзинама јер су интегрални део кластера мрежа комплексног система. Најзад, они најчешће измичу доминантним интерпретативним алатима, што претпоставља настајање „семантичке празнине”, празан ход и редуданцу, што доводи до употребе зомби појмова.

\section{Трећа линија}

Настајање кластера честица догађаја који мењају правила игре и њихово преплитање оцртава оно што се назива „великим убрзањем”. Оно би се могло узети као трећа линиja, која је конститутивни моменат у настајању перманентне кризе. Битна одлика догађаја који мењају правила игре је да су отворени за упад виртуелних честица догађаја па тако и за актуелизацију различитих потенцијала унутар неког стања ствари. Пре него што се актуелизују ови догађаји, најпре, дестабилизују и доводе у питање затечени статус стања ствари, међутим када се актуелизују они мењају статус стања ствари. Као конститутивни моменти једног кластера догађаја који повезује хетерогене честице догађаја, ови догађаји често остају неопажени унутар само једног регистра система и његове доминантне реалности. Чини се да је „велико убрзање" могуће разумети као почетак брисања границе између планетарног система и социо-економског система, природе и цивилизације, као ефекат неконтролисаног прелажења прагова унутар оба чије су последице несагледиве и непрорачунљиве. „Велико убрзање” је започело као последица људских активности, а индикатори - има их 24 који се узимају су како социо-економски (економски раст, популација, директна инострана улагања, потрошња енергије, телекомуникације, транспорт, употреба воде и сл.), тако и они који се тичу система земље (пораст карбон диоксида или метана, киселост океана, површинска температура, губитак тропских шума и сл.). Ови индикатори указују на потенцијално радикалне промене читавог глобалног контекста које би настале са преласком онога што научници називају планетарним границама и праговима система земље. 
Почетак „великог убрзања” истраживачи лоцирају око 1950. године када постаје очигледно да су велике промене у систему земље у вези са глобалним економским системом. Тако се прва детонација атомске бомбе - понедељак 16. јули 1945. у пустињи Новог Мексика - може узети као тачан датум започињања „великог убрзања” и промена које настају са њим. Са великим убрзањем постало је очигледно да људски утицај на систем земље не делује у одвојеним, једноставним узрок-последица реакцијама. Тај утицај више није могуће свести на неку релативно затворену „сцену производње" која је одвојена од других сцена у природи. Један тип промена које изазива човек узрокује велики број реакција у систему земље, које пролазе кроз систем често се стапајући са обрасцима природних варијабила. Ове реакције ретко следе линеарне ланце, већ много чешће узајамно делују једне на друге, некада умањујући ефекте људског деловања, а некада их појачавајући. Реакције постају повратне спреге (feedback), који пак могу довести до даљих утицаја који су потпуно страни функционисању система замље. ${ }^{6}$

Тачку окрета унутар друштвене машине која коренспондира са „великим убрзањем”, детектује и Делез на крају првог тома књиге о филму, када наводи неке од разлога (социјални, политички, економски или уметнички), који су довели до кризе класичног филма. ${ }^{7}$ Тренутак када започиње ова криза делатне слике он лоцира управо након Другог светског рата. Као разлози за ову кризу наводе се рат са његовим последицама, колебање „америчког сна”, пробуђена свест мањина, инфлација слика како у свету тако и у главама људи, литерарни експерименти, криза Холивуда и сл. Који су то индикатори или знаци из којих настаје нова врста слике која недвосмислено упућује на прве ефекте великог убрзања? Пре свега, класична слика која губи своју доминантну улогу јер постаје све мање уверљива у свом настојању да што прецизније оцрта неко стање ствари и његов хоризонт догађаја. Она више не упућује на стање ствари које би било свеобухватно или синтетичко, са јасно постављеним границама, већ је пре у питању дисперзивна ситуација која је отворена за контигентне упаде споља. Сама реалност расипа све личности и оне постају многоструке са слабим међусобним утицајима и повезивањима, постајући час главне, час секундарне. Истовремено мења се логика града и гомиле, јер се са вертикале тежиште премешта на хоризонталу, а урбана маса

6 www.igbp.net/globalchange/greatacceleration

7 Делез, Ж. (1998) Покретне слике, Сремски Карловци - Нови Сад: Издавачка њижарница Зорана Стојановића, стр. 241. 
субјеката захваћена брауновским кретањем, прераста у мноштво сингуларности где свако иде својим послом.

Самим тим линија универзума, дакле, она линеарност где су се догађаји низали једни за другим, постаје изломљена. У тако непотпуној и дисперзивној реалности, случајност постаје једина нит водиља, док су спојеви и везе намерно слаби. Догађаји или касне или долазе прерано, у сваком случају, они се намећу споља и не припадају онима којима се дешавају; то су празни догађаји који не успевају да се вежу за оне који их изазивају или подносе. Разлог за то лежи у томе што догађаји настају у тачкама пресека тих брауновски оцртаних путања од којих је свака различитих брзина и интензитета.

Шетња, скитња и непрекидно брауновско кретање тамоамо надомештају сензо-моторну ситуацију, губећи сваки аспект иницијације и ослобађајући се сваке активне и афективне структуре која јој је давала макар и неодређену усмереност. Док класични реализам смешта акције у одређене просторно-временске целине, дотле се модерна скитња одиграва у раствореним и некарактеристичним просторима. Губитак вере у свет настаје као ефекат те немогућности класичне слике да обухвати одређене просторно-временске целине и да их уопште конституише у неко стање ствари. Управо та немогућност стабилизовања машина видљивости и режима исказивости, као конститутивних момената неког статуса стања ствари, чини класичне слике све мање уверљивим. Луталаштво и тумарање између различитих фрагмената и њихово насумично повезивање успостављају урбаног номада, наследника бењаминовског фланера, као фигуру сингуларности која ће, у зависности од ситуације, развијати своје модусе егзистенције као стратегије опстанка, од јунака филма Голи у седлу (Easy Rider, 1969) до јунака из Великог Лебовског (Big Lebowsky, 1998) браће Коен.

Поставља се питање шта у том свету без тоталитета и повезаности одржава целину. Делезов одговор је једноставан: „клишеи и ништа више, само и свуда клишеи...”. 8 У тој непотпуној и дисперзивној реалности општи клишеи једне епохе или једног тренутка су ти који све то учвршћују. Истовремено, те неодређене слике и анонимни клишеи који су у оптицају у спољашњем свету продиру у свачију свест и образују његов унутрашњи свет. Тако субјект постаје клише међу осталим клишеима у свету који га окружује, јер свако мисли и осећа, мисли о себи и осећа себе, помоћу психичких клишеа. Спољашњи (физички, оптички и звучни) и

8 Исто. 
унутрашњи (психички) клишеи се међусобно потхрањују и надопуњују у једној глобалној организацији беде. Да би се дошло до ове организације, неопходно је да беда продре у унутрашњост свести и да дође до изједначавања унутрашњости и спољашњости како би људи уопште могли да се подносе и да подносе свет. Управо ова организација и дистрибуција беде упућује на велику и моћну заверу која је нашла начин да пусти у оптицај клишее, како од спољашњег ка унутрашњем, тако и од унутрашњег ка спољашњем. Обзиром да у том дисперзивном свету више не постоји неки заверенички центар, онда се злочиначка завера, као организација Власти, која се користи „техничком репродукцијом”, изједначава својим пре свега медијским ефектима.

Оно што се оцртава из ових слика и знакова промене је распадање доминантног модела сцене или паноптичких модли, за које су светлост и поглед, још од Париске комуне били конститутивни моменти једног доба које је Хајдегер одредио као „доба слике света”. Захваљујући овом моделу свет je био позорница, или скуп различитих сцена, на којој су се одигравали догађаји чији су се актери (глумци и режисери) смењивали у зависности од историјских околности. Ако је до почетка „великог убрзања” још постојала нека илузија о одвојености природе и цивилизације са њим ова граница почиње да бледи, а ефекат овог процеса је промена света који се више не сагледава као позорница, већ као мрежа. Утолико постаје јасно да човеков утицај није више нешто што се одиграва на некој мање или више изолованој сцени у једном или више регистара, већ је тај утицај пре серија кризних догађаја који се не-линеарно шире формирајући мреже кластера у готово свим регистрима. Нисмо више у грчком амфитеатру, као што исто тако нисмо више ни у паноптичкој машини и њеним затвореним модлама, већ у свету-мрежи са безброј модулација различитог интензитета о чијој комплексности још не знамо довољно.

Унутар сваке од ове три линије појединачно, али и унутар њихових безбројних преплитања, две врсте кризних догађаја могу бити различитог интензитета и трајања, од инцидента веома високог интензитета, до догађаја који се дуго одвијају (slow motion events) тако да измичу уобичајеној детекцији. Осим тога, ова два типа догађаја могу прелазити један у други, тако да нешто што се чинило готово рутинским (update event) прерасте у game-changer event и обрнуто: да оно за шта се веровало да може променити правила игре заврши у догађају који побољшава или крпи рупе унутар система. Можда је управо у тренутку у коме се одлучује о будућој политици људског рода, како би то рекао Слотердајк, 
неопходно да ретроактивно реконструишемо неке кризне догађаје како би видели којој класи догађаја припадају, који интензитет и трајање имају и да ли смо уопште у могућности да утичемо на њих. Данас би се могло рећи да су, са преласком у Антропоцене, ова два система заправо два лејера једног света и да се кризни догађаји који настају на њима шире унутар оба.

Чињеница да се догађаји који мењају правила игре повезују у кластере најближа је ономе што многи теоретичари називају перманентном кризом, бескрајном кризом и сл. Тако ће у једном интервју (Frankfurter Allgemeine Zeitung), Агамбен констатовати како је појам „криза” постао поштапалица модерне политике и већ одавно се у свим сегментима друштвеног живота одомаћио као нешто нормално. Подсећајући да се реч криза састоји од два семантичка корена: медицинског који означава ток болести и теолошког који се односи на судњи дан, он истиче да оба значења данас пролазе кроз трансформацију која их лишава историјског контекста. Данас је криза постала трајно стање па самим тим и инструмент моћи, која служи легитимизацији политичких и економских одлука, које практично обесправљују грађане и одузимају им било какву могућност одлучивања. Важно је схватити да је бесконачна криза, попут ванредног стања, неспојива са демократијом. Тако је по Агамбеновом суду неопходно да речи „криза” вратимо њено првобитно значење: тренутна процена и избор. Проблем са оваквим захтевом је пре свега у томе што нас суочава са нашим разумевањем стања перманентне кризе. Уколико је стање које називамо перманентном кризом кластер догађаја који мењају правила игре, тачније топологију читавог друштвеног поља, то претпоставља појаву нових сила које актуелним стањима ствари и виртуелним честицама догађаја које их прелећу, додељују нови смисао. У том случају повратак на изворно значење појма кризе промашује управо стога што не узима у обзир ову промену читавог поља насталу преплитањем ове три линије.

У средишту промене читаве топологије поља налази се један процес одвајања који многи теоретичари називају „разводом". Тако је „развод” за Баумана одвајање моћи и политике, за Жижека одвајање капитализма и демократије, док је за Бернарда Стиглера то развод између техничких система и социјалних организација. У сваком случају појава овог процеса у различитим регистрима као ефекат има перманентну кризу и дезоријентацију. У том смислу се може разумети Стиглерова опаска да се данас основна оријентација показује недовољном и да патимо од дезоријентације као такве. Ова дезоријентација настаје као ефекат брзине техничког 
развоја која од индустријске револуције наставља да убрзава. Тако долази до драматичног повећања раздаљине између техничких система и социјалних организација као таквих, па се утолико усаглашавање или преговарање између њих чини немогућим, а самим тим се и „њихов коначни развод чини неизбежним". 9

Бауман прецизира да је резултат овог развода одсуство деловања које би било способно да учини оно што свака „криза” по дефиницији захтева: изабрати пут којим даље треба ићи и применити терапију која одговара том избору. Ово одсуство деловања, чини се да ће наставити да паралише трагање за ваљаном солуцијом, све дотле док се „моћ и политика, сада у стању развода, поново не венчају" ${ }^{\prime \prime}$. Но, поновно венчање разведеног пара је прилично редак догађај, тако да би у овом случају чекање да до тога дође могло да прерасте у лошу бесконачност. Најзад, појава ових одвајања има још један ефекат попут оног који је Лео Маркс назвао „семантичком празнином” (semantic void). То је ситуација када се постојећи језик испоставља неадекватним за нове историјске услове, због тога што историјске промене превазилазе лингвистичке ресурсе које би могле да их изразе и анализирају. Таква празнина се појавила крајем 19. века и могуће је да се она поново појављује на почетку 21. века. Тако „семантичка празнина" може бити разлог конфузије у одређењу којем од ова два типа догађаја нека криза припада, али исто тако и зашто поједине догађаје који мењају правила игре не препознајемо као кризе или их уопште не детектујемо. Она исто тако може бити разлог што префикс пост све више задобија значење краја, па се онда говори о крају историје, уметности, хуманизма, теорије и сл. превиђајући ону Слотердајкову опаску да се пост у новој констелацији може заменити са маргинализацијом. У првом случају, које би одговарало неком ранијем стању ствари, крај задобија оно значење које би одговарало могућем разрешењу кризе у њеном изворном значењу. У другом случају, које претпоставља промењену топологију читавог поља и нову констелацију стања ствари, не ради се о крају, већ о измештању на маргину. У новонасталој констелацији тако се пре може говорити о маргинализацији уметности, хуманистике и слично, него о њиховом крају.

9 Stiegler, B. (2008) Technics and Time, 2: Disorientation (Meridian: Crossing Aesthetics), Stanford University Press, p. 3.

10 Bauman, Z. and Bordoni, C. (2014) State of Crisis, Polity, p. 12. 


\section{ЈОВАН ЧЕКИЋ}

\section{С оне стране}

Оно што се са Слотердајковим и Фукоовим анализама као и са индикаторима великог убрзања, детектује као заједничка тачка окрета од које започињу да се одвијају три линије, заправо је стварање услова за настајање кластера догађаја који мењају правила игре, а чији ефекат је промена односа сила па самим тим и топологије читавог поља. Најзад, можда је појава „семантичке празнине” симптом једног фундаменталног расцепа између капиталистичког система и света где се свет почиње мењати откривајући унутрашње границе самог система. Тако би се из овог угла пре могло говорити о промени света, где је позни капитализам, са инфлацијом техно-слика тек врхунац света-слика, који почиње да се распада и прелази у свет-мрежу. Дакле оно што зовемо перманентном кризом можда је пре свега стање транзиције из једног у други свет. Кластери догађаја који мењају правила игре претпостављају стварање нових и другачијих политичких и технолошких услова за отварање једног простора „с оне стране”. Али поставља се питање „с оне стране” чега? Пре свега, до сада важећих граница и прагова система, дакле, како унутар политике, тако и технологије, које су, као две стране истог новчића, неодвојиви моменти у промишљању ових кластера.

Могло би се рећи да „семантичка празнина” има још један колатерални ефекат који се препознаје као недостатак и истрошеност идеја како би нови свет требало да изгледа. Хуманизам је конститутивни моменат настанка света-слике у коме се, самим тим, човеку додељује место свих повезивања на једној позорници света на коју је бачен. Међутим, уколико се префикс пост из пост-хуманизма схвати у оном Слотердајковом кључу као маргинализација и децентрирање човека, јасно је да се обриси тог новог света већ сада радикално разликују од оног пређашњег. Оно што се најављује са новим светом је промена стања ствари у којем човек више није тачка свих повезивања, већ само једно од могућих чворишта унутар много комплекснијих мрежа хетерогених ентитета. Поставља се питање да ли је неки нови хуманизам уопште могућ, ако истовремено укључи и овај моменат маргинализације човека, као суочавање са једним апсолутним хоризонтом мноштва, насупрот релативном хоризонту досадашњег хуманизма?

Оно што се данас назива перманентном кризом прераста у стање у коме је промена једина константа, при чему се та стопа промене све више повећава. То претпоставља да уколико се данашња перманентна криза схвати као симптом 


\section{JOBAН ЧЕКИЋ}

транзиције из једног у други свет, да би оно што се у том процесу маргинализује (уметност, хуманистика и сл.) требало постати конститутивним моментом у стварању и осмишљавању новог света. Истовремено, то би значило да ако је хуманизам заснивао на универзалистичким претензијама клуба или секте писмених, неки нови хуманизам, уколико је уопште могуће више и говорити о хуманизму, претпостављао би глобалне мреже које конституишу једну интелигенцију poja (swarm intelegence) која се шири по читавом друштвеном телу трансформишући га у свет умреженог мноштва с оне стране капитализма.

\section{ЛИТЕРАТУРА:}

Bauman, Z. and Bordoni, C. (2014) State of Crisis, Polity.

Делез, Ж. (1998) Покретне слике, Сремски Карловци - Нови Сад: Издавачка њижарница Зорана Стојановића.

Фуко, М. (1998) Треба бранити друштво, Нови Сад: Светови.

Слотердајк, П. (2001) У истом чамиу, Београд: Београдски круг.

Stiegler, B. (2008) Technics and Time, 2: Disorientation (Meridian: Crossing Aesthetics), Stanford University Press.

Џој, Б. Зашто нисмо потребни будућности, Врата панике. Тело, друштво и уметност у мрежи технолочке дереализаиије, приредио Копицл, В. (2005), Нови Сад: Транс.

\section{Вебографија:}

www.igbp.net/globalchange/greatacceleration

www.independent.co.uk 


\title{
ЈОВАН ЧЕКИЋ
}

\section{Jovan Čekić}

Faculty of Media and Communications, Belgrade

\section{PERMANENT CRISIS}

\begin{abstract}
The term crisis is primarily associated with the world economic crisis and thus the question of relationship between capitalism and crisis comes to the fore. Is a crisis something that disrupts normal functioning of the system from the outside and assumes short duration followed by restoration of balance and return to the normal process of market regulation and setting? Or is it an essential and immutable characteristic of the capitalist mode of production, which leads to conclusion that capitalism is historically presented as a continuous movement from one crisis to another, indicating permanent crisis as the main feature of late capitalism and the present moment? What are the consequences of entering into a permanent crisis?
\end{abstract}

Key words: crisis, capitalism, humanism, post-humanism, biopolitics, biomass

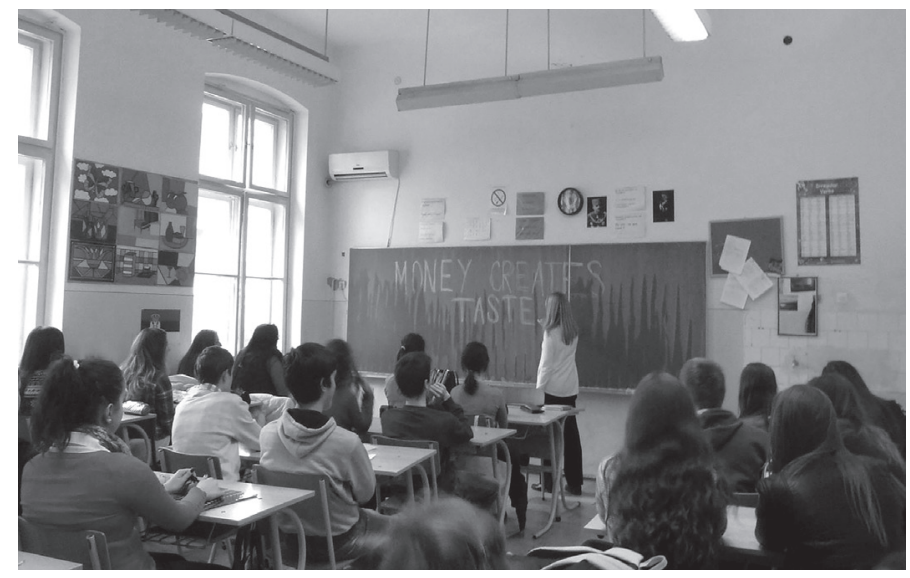

Катарина Илишковић, Money Creates Taste (After Jenny Holzer), 1-3, фото-манипулација, 2014. 